\title{
NOTES ON SOME AMERICAN TINGITIDAE (HEMIPTERA)
}

\author{
CARL J. DRAKe, \\ Ames, Iowa
}

The present paper is based almost entirely upon a small collection of American Tingitidæ kindly loaned to the writer by Nathan Banks of the Museum of Comparative Zoology, Harvard University, Cambridge, Massachusetts. In addition to Corythucha decepta, described below as new, this collection is represented by Monanthia monotropidia Stäl, Gamboa, Canal Zone, July 9, 1924, collected by Nathan Banks; Teleonemia prolixa Stäl, Barro Colorado, July 23, 1924, N. Banks; Teleonemia albomarginata Champion, Barro Colorado, Canal Zone, July 19, 1924, and Rio Frio, Mgd., Colombia, P. J. Darlington; Teleonemia sacchari Fabr., Bella Vista, Panama, July 7, 1924, N. Banks ; Acalypta ovata Osborn and Drake; Smoky Mts., N. C.-Tenn., Newfound Gap, Elevation 5,000-5,200 ft., collected in moss by Nathan Banks; Acanthocheila armigera Stàl, Bella Vista, Canal Zone, July 7, 1924, N. Banks ; Gargaphia nigrinervis Stäl, Rio Frio, Colombia, May 15, P. J. Darlington; Corythaica planaris Stäl, Red Tank, Canal Zone, N. Banks; Corythucha padi Drake, Hood River, Oregon, Sept. 5, 1917, F. R. Cole; Corythucha obliqua Osborn and Drake, Carmel, Cal., June 22, 1918, C. L. Hubbs; Corythucha spinosa Duges. The writer is indebted to Mr. A. A. Nichol for the specimens of Corythucha sagillata, n. sp., from Arizona.

\section{Corythucha decepta, $\mathrm{n}$. sp.}

Moderately large, testaceous, the pronotum and a more or less distinct band near the base of the elytra brown. Hood long, much smaller and placed a little farther for- 
ward on the pronotum than in either C. setosa Champ. or C. eriodictyonæ Drake. Pronotum finely punctate, moderately swollen; lateral carinæ not strongly elevated, the areolæ very small, terminating anteriorly just behind the tumid area. Antennæ and legs as in C. setosa. Paranota large, rather closely reticulated, the lateral spines wanting except along anterior margin. Median carina very low, not distinctly arched, uniseriate, the areolæ very small. Elytra broad, with lateral spines along the costal margin; tumid elevation very small, not very distinct. Costal area broad, widely reticulated, irregularly triseriate, with some of the nervelets near the base darker and forming an indistinct band. Wings a little longer than abdomen. Areolæ hyaline.

Length, $3.65 \mathrm{~mm}$; width, $1.82 \mathrm{~mm}$.

Holotype, male, and allotype, female, San Miguel, Hidalgo, Mexico, collected by Dr. W. M. Mann, Museum Comparative Zoology. Paratypes, 13 specimens, taken with the type. The smaller hood, unarmed, paranota and elytra, and much smaller tumid elevations of elytra separate this species at once from $C$. setosa Champ., C. eriodictyonæ Drake, C. pacifica Drake and C. sphæraceæ Drake. The lateral carinæ are formed as in $C$. setosa and not as in the other species mentioned above. The hood is not abruptly constricted and much more elevated than the median carina.

Corythucha sagillata, n. sp.

Moderately large, whitish testaceous, conspicuously marked with brown and fuscous. Hood moderately large, strongly and abruptly constricted near the middle, very strongly compressed and narrowed in front; posterior portion mostly brown, inflated and elevated. Median carina about half as high as hood, arched, there biseriate and with a brown patch. Lateral carinæ whitish, raised anteriorly, terminating a little behind the hood. Paranota with brown markings, rather closely reticulated. Antennæ testaceous, clothed with a few extremely long bristly hairs, the apical segment pale brown.

Elytra moderately constricted, with the usual crossbands; costal area somewhat irregularly triseriate, areolæ 
(except in transverse bands) hyaline; tumid elevation large, with large brown spot. Wings longer than abdomen. Rostrum extending almost to end of rostral channel, the tip blackish. Legs testaceous. Nervures of elytra, carinæ, hood and paranota with a few erect spines.

Length, $3.51 \mathrm{~mm}$.; width, $2.10 \mathrm{~mm}$.

Holotype, female, and two paratypes, females, Santa Catalina Mts., Arizona, July 15, 1925, alt. 5000-6000 ft., collected on Vauquelinia californica (Torr.) Sarg. by A. A. Nichol. This is a very pretty and elegantly marked species. It is perhaps most closely allied to $C$. elegans Drake, differing in the larger tumid elevations, more constricted elytra and the different formed hood. The types are in the collection of the author.

\section{OVIPOSITION OF THE ICHNEUMONID ITOPLECTIS CONQUISITOR (SAY) IN A LARVA OF PYRAUSTA NUBILALIS HUBN.}

By Milton F. Crowell

During the summer of 1932 I was fortunate enough to see a female of Itoplectis conquisitor (Say) parasitize a larva of the European corn borer, Pyrausta nubilalis Hubn.

When first observed the female hymenopteron was running up and down over the upper part of a corn stalk, perhaps a foot below the tassel. Closer examination revealed that she was paying attention to a short section of the stalk just above a hole opening into a tunnel of the corn borer. She approached the hole, felt around it with her antennæ, then proceeded to explore with her antennæ the stalk just above it. After a short time, during which she felt over most of the area of the stalk for perhaps three inches above the hole, she stopped and thrust her ovipositor vertically into the corn stalk. She remained motionless for an estimated time of fifteen to twenty seconds. She then withdrew her ovipositor and flew away.

Cutting open the stalk I found a mature larva of Pyrausta nubilalis in the burrow, directly under the spot where Itoplectis conquisitor had thrust her ovipositor into it. 

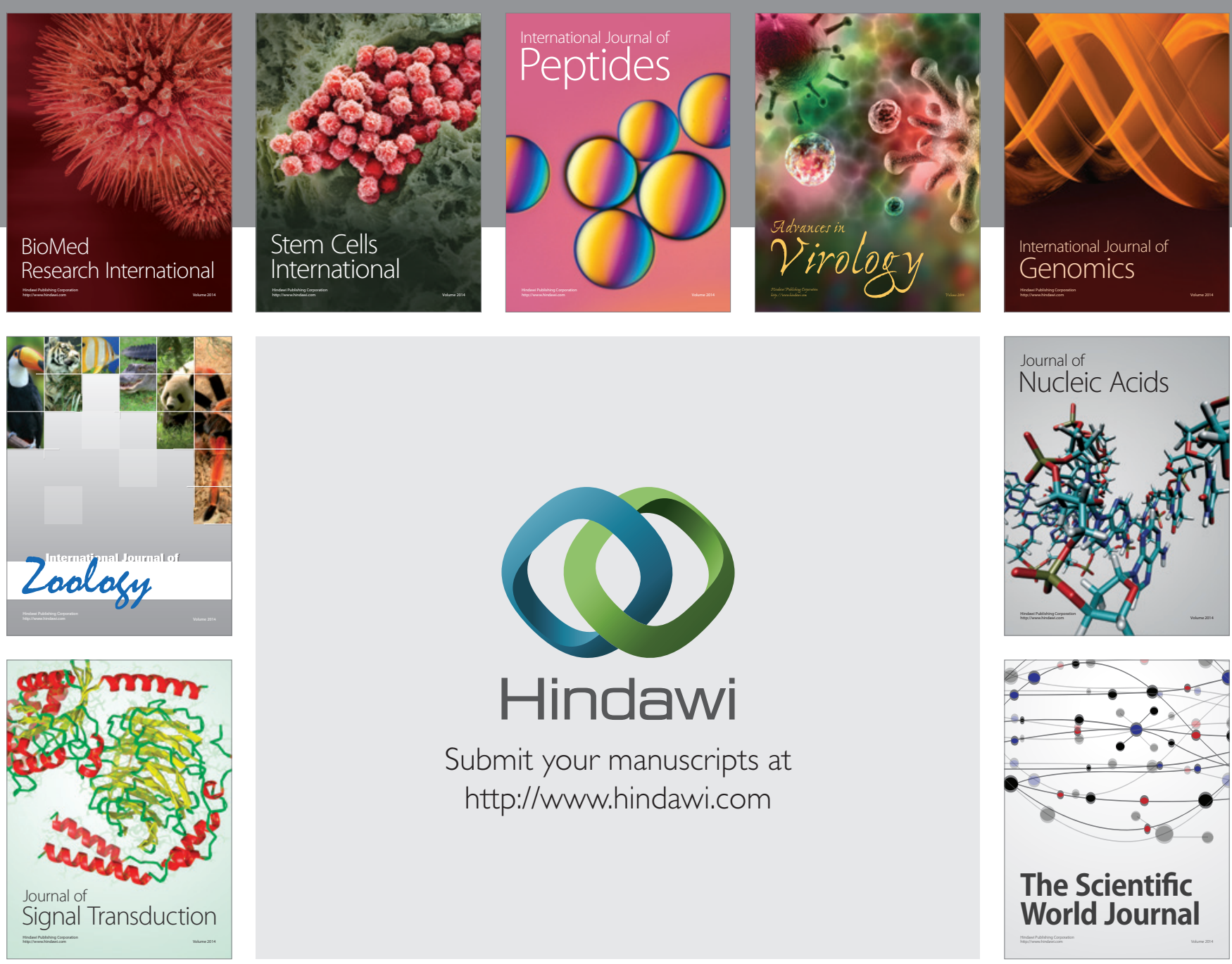

Submit your manuscripts at

http://www.hindawi.com
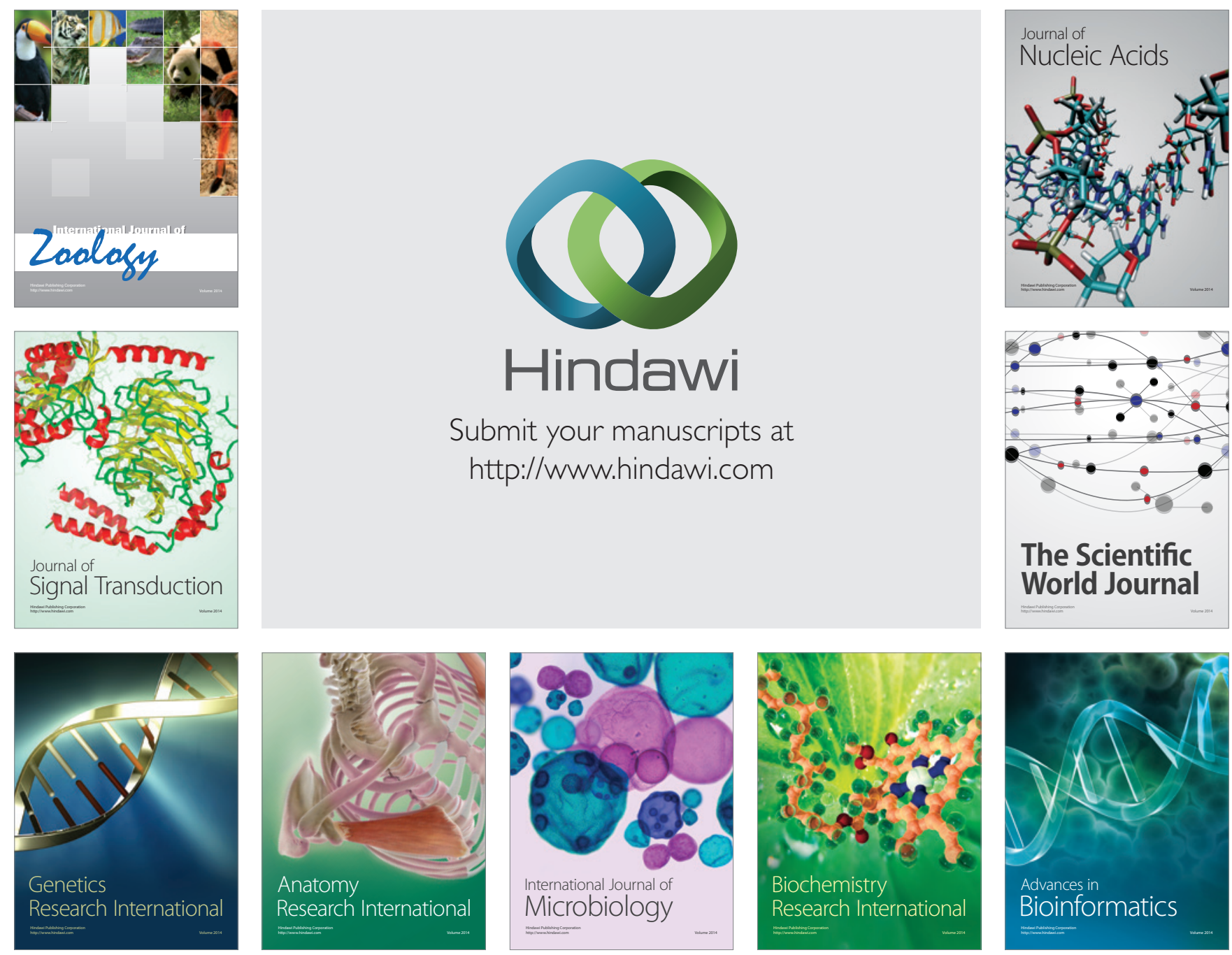

The Scientific World Journal
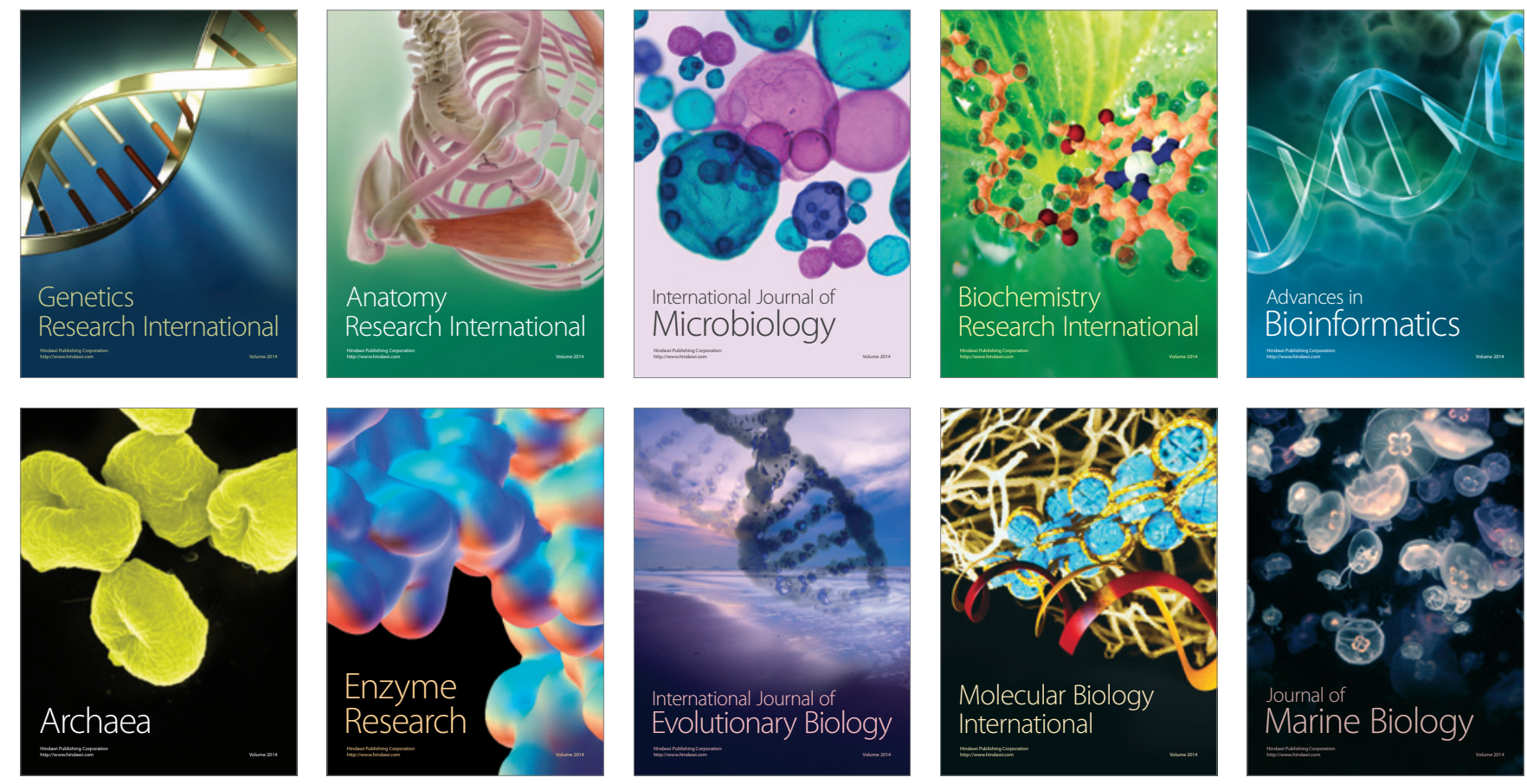